\title{
Effects of amiodarone on sinus node in man
}

\author{
PAUL TOUBOUL, GEORGES ATALLAH, ALAIN GRESSARD, \\ AND GILBERT KIRKORIAN
}

From the Laboratory of Clinical Electrophysiology, Hôpital Cardiovasculaire et Pneumologique, Lyon, France

SUMMARY The effects of amiodarone on the sinuatrial node were studied in 24 patients after an intravenous injection of the drug $(5 \mathrm{mg} / \mathrm{kg})$. Sinuatrial function was assessed by rapid atrial pacing and premature atrial stimulation. Sinus cycle length did not change significantly, but the corrected sinus node recovery time was prolonged. While there was no significant change in sinuatrial conduction time, prolongation of the non-reset zone in 14 cases, as well as the abolition of the plateau in 2/24 patients, suggested that conduction of the atrial responses to the sinus node might have been depressed.

Amiodarone was initially used as an antianginal drug (Vastesaeger et al., 1967), but was later found to possess antiarrhythmic properties. Many clinical studies have confirmed the efficacy of this drug against both supraventricular and ventricular arrhythmias (Coumel and Bouvrain, 1973; Fauchier et al., 1973; Rosenbaum et al., 1976). Amiodarone was found especially effective in controlling refractory atrial arrhythmias associated with the Wolff-Parkinson-White syndrome (Rosenbaum et al., 1974). Though amiodarone was increasingly used for clinical purposes, its therapeutic advantages were somewhat counteracted by various side-effects such as cutaneous disorders (Wanet et al., 1971; Morand et al., 1972), corneal deposits (Francois, 1968; Verin et al., 1971), and hyperthyroidism or hypothyroidism because of the presence of iodine in the compound (Barrillon and Himbert, 1971; Grand, 1975; Pritchard et al., 1975). As severe bradycardia was also observed (Van Schepdael and Solvay, 1970), we carried out the present study so as to elucidate the effects of amiodarone on sinus node function.

\section{Patients and methods}

Twenty-four patients were studied, 13 men and 11 women, aged from 51 to 77 years (mean: 64). None of the patients was suffering from sinuatrial disorder as defined by severe bradycardia of less than $50 /$ min or episodes of sinus arrest. However, during the study, two subjects exhibited heart rates of 52 and $55 / \mathrm{min}$, respectively, so that some degree of sinuatrial involvement could not be excluded. In two others, sinus tachycardia was noted, presumably

Received for publication 19 June 1979 caused by anxiety. Atrioventricular conduction abnormalities were present in 16 cases (long PR interval in one and bundle-branch block or fascicular block in 15). Despite theoretical reservations, these patients were included in the study, since there was no evidence that they would be more prone to sinuatrial alteration than the others.

Electrophysiological studies were performed in the postabsorptive, non-sedated state, after informed consent had been obtained. Of the 24 patients, 22 complained of syncope or dizziness (Table). The remaining two (cases 1 and 21) had latent electrocardiographic abnormalities. All medication with cardiac effects was stopped at least eight days before the study. The procedure was similar to that previously reported (Touboul et al., 1975). Four electrode catheters were introduced percutaneously through the right and left femoral veins. Of these, a tripolar catheter was used for recording His bundle activity according to Scherlag (Scherlag et al., 1969), and another was positioned at the apex of the right ventricle for electrical pacing. The remaining two catheters were inserted into the right atrium. A bipolar electrogram was recorded at the junction of the superior vena cava and the external border of the atrium. In addition, atrial stimulation was performed in the region of the sinus node. A modular programmable stimulator was used $^{1}$. Electric impulses were rectangular of $1.5 \mathrm{~ms}$ duration, and were delivered at twice diastolic threshold intensity. We used an eight channel direct ink jet recorder ${ }^{2}$. Paper speed during the study was $100 \mathrm{~mm} / \mathrm{s}$. Intracardiac electrograms were transmitted through amplifiers. The potentials in the His

${ }^{1}$ Tektronix, Oregon, U.S.A.

${ }^{2}$ Elema Schönander, Sweden. 
Table Data on patients

\begin{tabular}{|c|c|c|c|c|c|c|c|c|c|c|}
\hline \multirow{2}{*}{$\begin{array}{l}\text { Case } \\
\text { no. }\end{array}$} & \multirow{2}{*}{$\begin{array}{l}\text { Age } \\
(y)\end{array}$} & \multirow[t]{2}{*}{$\operatorname{Sex}$} & \multirow[t]{2}{*}{ Clinical data } & \multirow[t]{2}{*}{$E C G$} & \multicolumn{2}{|c|}{$\begin{array}{l}\text { Sinus cycle length } \\
\text { (ms) }\end{array}$} & \multicolumn{2}{|c|}{ CSNRT (ms) } & \multicolumn{2}{|c|}{$E A S A C T$} \\
\hline & & & & & Before & After & Before & After & Before & After \\
\hline $\begin{array}{l}1 \\
2 \\
3\end{array}$ & $\begin{array}{l}65 \\
55 \\
51\end{array}$ & $\begin{array}{l}\mathbf{M} \\
\mathbf{M} \\
\mathbf{F}\end{array}$ & $\begin{array}{l}\text { No symptom } \\
\text { Syncope } \\
\text { Hypertension, AHD, } \\
\text { syncope }\end{array}$ & $\begin{array}{l}\text { RBBB } \\
\text { RBBB } \\
\mathbf{N}\end{array}$ & $\begin{array}{l}875 \\
580 \\
950\end{array}$ & $\begin{array}{l}840 \\
550 \\
965\end{array}$ & $\begin{array}{l}290 . \\
140 \\
250\end{array}$ & $\begin{array}{l}350 \\
150 \\
230\end{array}$ & $\begin{array}{l}210 \\
120 \\
110\end{array}$ & $\begin{array}{r}210 \\
150 \\
85\end{array}$ \\
\hline $\begin{array}{l}4 \\
5 \\
6\end{array}$ & $\begin{array}{l}64 \\
66 \\
77\end{array}$ & $\begin{array}{l}\mathbf{M} \\
\mathbf{F} \\
\mathbf{F}\end{array}$ & $\begin{array}{l}\text { Hypertension, syncope } \\
\text { Syncope } \\
\text { Hypertension, AHD, } \\
\text { syncope }\end{array}$ & $\begin{array}{l}\text { LBBB } \\
\mathbf{N} \\
\mathbf{N}\end{array}$ & $\begin{array}{r}800 \\
1160 \\
1100\end{array}$ & $\begin{array}{r}850 \\
1000 \\
1050\end{array}$ & $\begin{array}{r}370 \\
60 \\
450\end{array}$ & $\begin{array}{l}300 \\
170 \\
520\end{array}$ & $\begin{array}{l}140 \\
110 \\
150\end{array}$ & $\begin{array}{l}130 \\
180 \\
200\end{array}$ \\
\hline 7 & 61 & $\mathbf{M}$ & $\begin{array}{l}\text { Diabetes, AHD, } \\
\text { palpitation, syncope }\end{array}$ & LBBB & 660 & 640 & 170 & 280 & 210 & 210 \\
\hline $\begin{array}{l}8 \\
9\end{array}$ & $\begin{array}{l}72 \\
71\end{array}$ & $\begin{array}{l}\text { F } \\
\text { F }\end{array}$ & $\begin{array}{l}\text { Hypertension, syncope } \\
\text { Syncope }\end{array}$ & $\begin{array}{l}\text { ILBBB } \\
\mathbf{N}\end{array}$ & $\begin{array}{l}930 \\
730\end{array}$ & $\begin{array}{l}870 \\
680\end{array}$ & $\begin{array}{l}260 \\
390\end{array}$ & $\begin{array}{l}470 \\
230\end{array}$ & $\begin{array}{l}220 \\
270\end{array}$ & $\begin{array}{l}230 \\
\text { No plateau } \\
\text { zone }\end{array}$ \\
\hline 10 & 63 & $\mathbf{F}$ & Syncope & $\mathbf{N}$ & 700 & 730 & 240 & 200 & 140 & 150 \\
\hline 11 & 72 & $\mathbf{M}$ & AHD, dizziness & OMI & 900 & 980 & 270 & 400 & 80 & 130 \\
\hline 12 & 58 & $M$ & PAD, syncope & $\mathbf{N}$ & 930 & 870 & 190 & 410 & 220 & 195 \\
\hline 13 & 59 & $M$ & Syncope & N & 900 & 870 & 280 & 370 & 250 & 300 \\
\hline 14 & 70 & $\mathbf{M}$ & PAD, syncope & $\begin{array}{l}\text { RBBB } \\
\text { LAH }\end{array}$ & 830 & 920 & 370 & 580 & 340 & 320 \\
\hline 15 & 68 & $\mathbf{F}$ & Syncope & $\mathbf{N}$ & 590 & 625 & 190 & 140 & 130 & 135 \\
\hline 16 & 56 & $\mathbf{M}$ & Syncope & $\begin{array}{l}\text { RBBB } \\
\text { LAH }\end{array}$ & 830 & 750 & 150 & 260 & 130 & 200 \\
\hline 17 & 70 & $\underline{\mathbf{F}}$ & Palpitation, syncope & N & 900 & 950 & 380 & 650 & 260 & 230 \\
\hline 18 & 76 & $\mathbf{F}$ & Hypertension, syncope & $\begin{array}{l}\text { RBBB } \\
\text { LAH }\end{array}$ & 830 & 980 & 290 & 320 & 250 & 210 \\
\hline 19 & 73 & $\mathbf{F}$ & Hypertension, syncope & N & 800 & 810 & 370 & 300 & 300 & 220 \\
\hline 20 & 58 & $\mathbf{M}$ & Syncope & $\begin{array}{l}\text { IRBBB } \\
\text { LAH }\end{array}$ & 800 & 800 & 230 & 250 & 200 & 160 \\
\hline 21 & 75 & $\mathbf{F}$ & RLD & LBBB & 710 & 810 & 280 & 290 & 190 & 160 \\
\hline 22 & 52 & $\mathbf{M}$ & Hypertension, syncope & VPB & 850 & 880 & 360 & 350 & 230 & 200 \\
\hline 23 & 57 & $\mathbf{M}$ & Dizziness & $\begin{array}{l}\text { 1st/degree } \\
\text { AV block }\end{array}$ & 650 & 680 & 270 & 470 & 250 & $\begin{array}{l}\text { No plateau } \\
\text { zone }\end{array}$ \\
\hline 24 & 70 & $\mathbf{M}$ & AHD, syncope & LBBB & 950 & 880 & 310 & 340 & 150 & 190 \\
\hline
\end{tabular}

Abbreviations: N, normal; AHD, atherosclerotic heart disease; PAD, peripheral arterial disease; RLD, restrictive lung disease; RBBB, right bundle-branch block; LBBB, left bundle-branch block; ILBBB, incomplete left bundle-branch block; LAH, left anterior hemiblock; VPB, ventricular premature beats; OMI, old myocardial infarction; CSNRT, corrected sinus node recovery time; EASACT, estimated atrio-sinuatrial conduction time.

bundle lead were filtered (recording frequencies: 50 to $700 \mathrm{~Hz}$ ). Five external leads were recorded simultaneously: I, II, III, V1, and V6. Either lead I or II, as well as one selected intracardiac lead, were visualised on an oscilloscope and all data were stored on magnetic tape.

Sinus node function was assessed using two methods. Sinus node recovery time was measured by rapid atrial pacing at successive rates of 110 , 130, 150, and 170 a minute (Mandel et al., 1971). Each rate was maintained for $30 \mathrm{~s}$. The pause between the pacing sequences was about one minute. Sinus node recovery time corresponds to the interval between the last paced $P$ wave and the first sinus $P$ wave. In this study we took account of the two relevant electrograms recorded in the intra-atrial lead. Times measured were corrected as a function of basic sinus cycle length, in accordance with the formula of Narula et al. (1972):

Corrected sinus node recovery time $=$ sinus node recovery interval - sinus cycle length.

The sinus cycle length was an average value, calculated from the five sinus cycles preceding each pacing sequence. Whatever the pacing rate, only the longest corrected sinus node recovery time was taken into account.

Sinuatrial conduction time was determined according to the technique of Strauss et al. (1973). Premature atrial depolarisation was induced during sinus rhythm at every eighth or tenth beat. The coupling interval was long at first but was subsequently reduced by periods of $20 \mathrm{~ms}$ until the effective refractory period of the right atrium was reached. A curve was constructed by plotting the A1-A2 coupling intervals along the abscissa and the A2-A3 return cycles along the ordinate. Normally, this curve comprises two parts. At long coupling intervals, an ascending limb calied the non-reset zone (zone 1) follows the compe asatory line. The return cycles then become constant, and form a horizontal segment or plateau zune, as atrial depolarisations reach and discharge the pacemaker cells (as noted in isolated preparations). Sinus node activity was then reset and, after a new cycle, induced an earlier $\mathbf{P}$ wave (Miller and Strauss, 
1974). Consequently the relevant $₫ 2-A 3$ interval, as determined in clinical studies, is presumed to include a sinus cycle and, in addition, the conduction time taken by the retrograde impulse to reach the sinus node, as well as the sinuatrial conduction time of the sinus beat after the pause. hence the following formula:

Sinuatrial conduction time $=$

$$
\frac{\text { A2-A3 interval - sinus cycle length }}{2}
$$

In this study, we used the estimated atriosinuatrial conduction time, as follows:

Estimated atrio-sinuatrial conduction time $=$ A2-A3 interval - sinus cycle

The A2-A3 intervals were measured from the first third of the plateau. The sinus cycle length was an average value, calculated from all the cycles immediately preceding the premature atrial stimulation. The graphs were examined independently by two physicians from our laboratory and satisfactory concordance was obtained.

We carried out repeated studies of sinus node function after slow intravenous administration (five minutes) of $5 \mathrm{mg} / \mathrm{kg}$ amiodarone hydrochloride. Premature atrial stimulation and overdrive tests were carried out successively. The fresh evaluation was started five minutes after termination of the amiodarone injection. Statistical analysis of the results was made using Student's t test for paired data.

\section{Results}

The data on sinus node function are given in the Table.

After amiodarone administration, sinus cycle length increased in 12 cases by a mean of $55 \mathrm{~ms}$, decreased in 11 by $58 \mathrm{~ms}$, and remained unchanged in one (NS).

Corrected sinus node recovery time was longer in 17 subjects (mean: $110 \mathrm{~ms}$ ) and shorter in the remaining seven (mean: $60 \mathrm{~ms}$ ). These changes are statistically significant $(P<0.02)$.

Estimated atrio-sinuatrial conduction time was determined before and after amiodarone in 22 patients. It lengthened in 10 cases by a mean of $38 \mathrm{~ms}$, diminished in 10 (mean $33 \mathrm{~ms}$ ), and did not change in two (NS). In the remaining two patients, the plateau zone was abolished after amiodarone administration (Fig. 1).

In addition, certain changes in the A1A2/A2A3 curve occurred after injection of the drug. Thus, the duration of the non-reset zone, expressed as a percentage of the mean sinus cycle, increased in 14/22

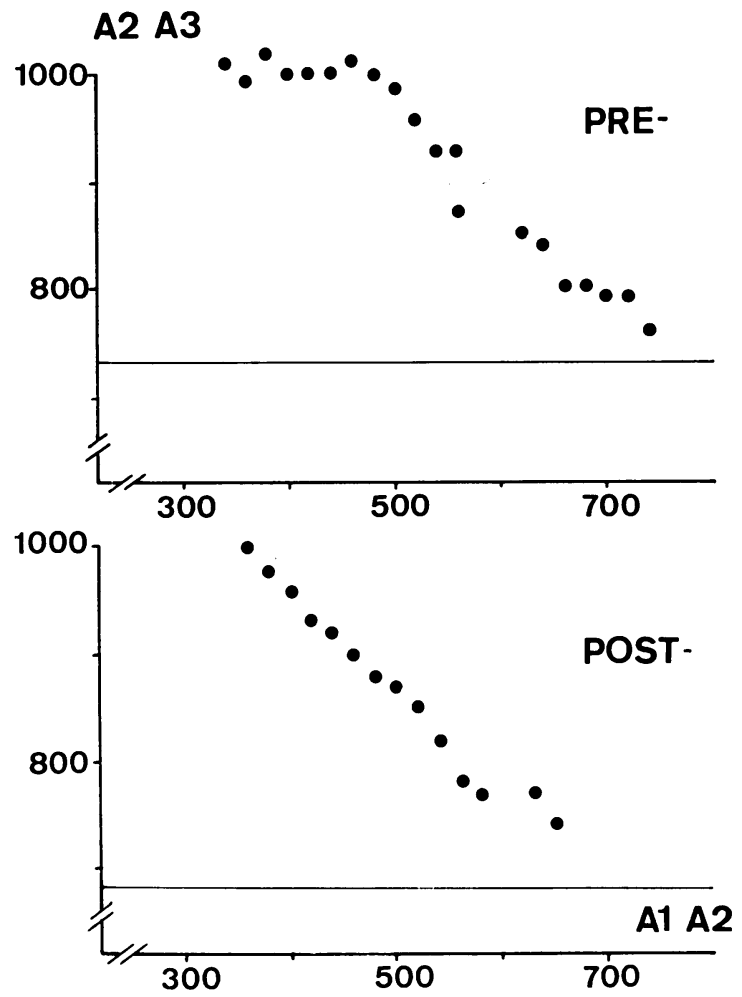

Fig. 1 Suppression of the plateau zone after amiodarone. Coupling intervals (A1-A2) are in abscissa, return cycles (A2-A3) in ordinate. Figures are in milliseconds. In the basal state (Pre-), both phases I and II are clearly visible. After amiodarone (Post-), only zone I is maintained. The suppression of the plateau suggests that the atrial depolarisations can no longer reach the pacemaker cells. The line parallel to the abscissa corresponds to the mean sinus cycle length.

patients by 11 per cent, decreased in seven by 2 per cent, and did not change in one $(P<0.005)$. Sometimes a smooth transition developed between the compensatory line and the plateau (Fig. 2). After early atrial depolarisations (coupling interval of less than 50 per cent of the sinus cycle), the return cycles showed a gradual increase in 10 patients, causing the latter part of the plateau to ascend (Fig. 3).

There were no untoward effects after the injection of amiodarone.

\section{Discussion}

The electrophysiological properties of amiodarone have been defined in previous studies. In isolated rabbit heart preparations, amiodarone prolonged the duration of the action potential in atrial and ventricular muscle without changing the resting potential 


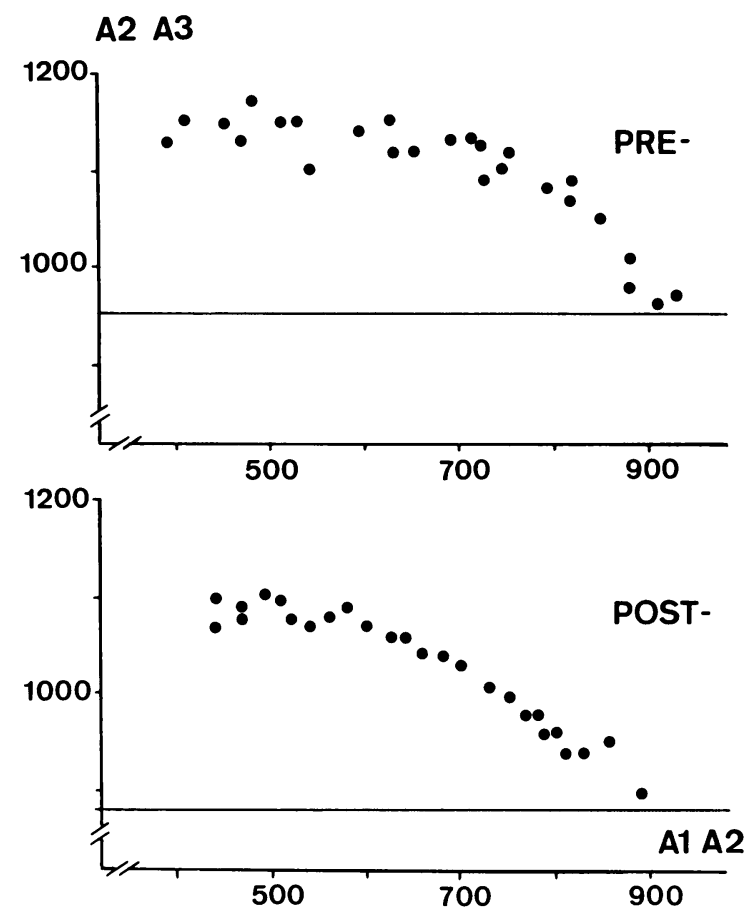

Fig. 2 Effect of amiodarone on sinuatrial conduction time. Estimated atrio-sinuatrial conduction time before amiodarone is $150 \mathrm{~ms}$ (Pre-). After amiodarone, it increases to $190 \mathrm{~ms}$ (Post-). In addition, segment $I$ is prolonged and moves down to below compensatory line before joining the plateau (see explanation in the text).

or the maximum rate of rise (Singh and Vaughan Williams, 1970). In man, atrioventricular nodal conduction was depressed after intravenous injection of $5 \mathrm{mg} / \mathrm{kg}$, whereas the His-Purkinje conduction time remained unchanged. The refractory periods of the atrioventricular conducting tissue (AV node and His-Purkinje system) and of the atrial and ventricular myocardium increased (Cabasson et al., 1976; Touboul et al., 1976a). The drug also lengthened the effective refractory period of the accessory pathway in patients with the WolffParkinson-White syndrome (Touboul et al., 1976b); Wellens et al., 1976).

As regards the effect of amiodarone on sinuatrial activity, slowing of the sinus node discharge was reported in the anaesthetised dog even after pretreatment with propranolol and atropine (Charlier, 1970). In rabbit sinus node preparations, amiodarone prolonged action potential duration and reduced the slope of spontaneous diastolic depolarisation (Goupil and Lenfant, 1976). Furthermore, recent studies using epicardial recording of sinus node activity have suggested that amiodarone might induce sinuatrial block (Castillo-Fenoy et al., 1978).

In man our results show an increase in sinus node recovery time after amiodarone administration. Surprisingly, sinus node cycle length did not alter significantly, a finding which contrasts with the well-known possibility that clinical use of the drug can induce bradycardia. Several checks of our batch of amiodarone by the manufacturer failed to disclose any abnormality which might have accounted for this finding. An explanation was also sought in the mode of intravenous administration, despite the fact that a slowing down of the sinus rate has been reported in similar studies (Touboul et al., 1976a). In this connection, the part played by autonomic changes should be mentioned, with special reference to the opposite effects of vasodilatation and partial adrenergic blockade on cycle length. In addition, it is conceivable that, after the doses of amiodarone used here, myocardial depression could have occurred, favoured in some of our patients by latent abnormalities (Sicart et al., 1977). The sympathetic

A2 $\mathbf{A 3}$

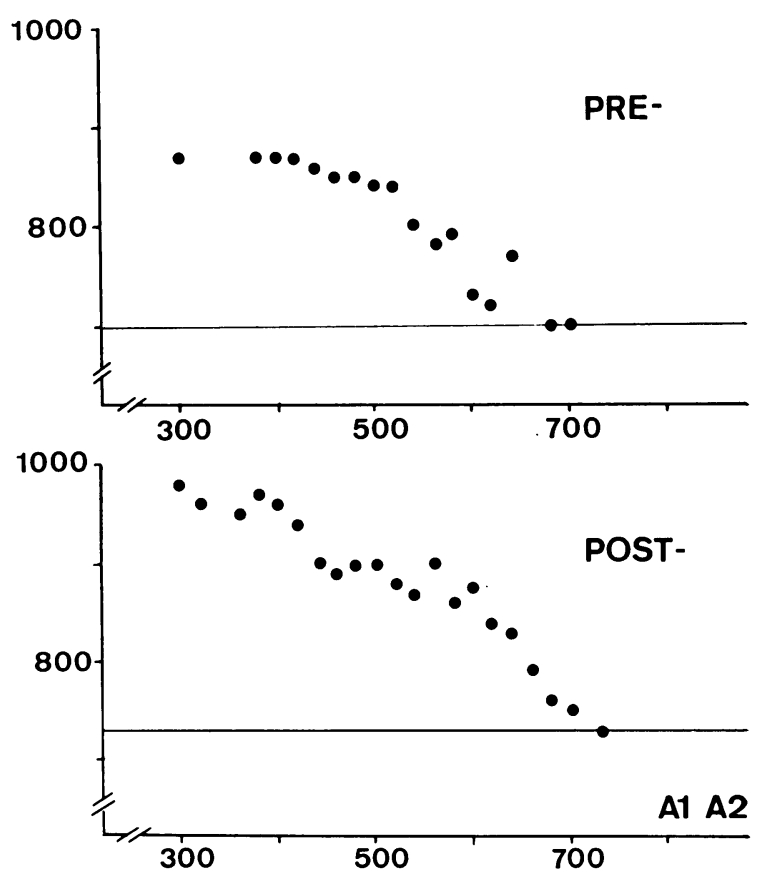

Fig. 3 Effect of amiodarone on the sinus node response after early premature atrial stimulation. Estimated atrio-sinuatrial conduction time measured at the first third of the plateau does not change after amiodarone. On the other hand, the terminal part of the plateau moves upwards as a result of return cycle lengthening (see explanation in the text). 
stimulation thus induced would have counteracted the direct effect of amiodarone on the sinus node.

It should be stressed that during premature atrial stimulation, abolition of the plateau zone was noted in two cases, after amiodarone. The drug thus occasionally suppressed retrograde conduction to the pacemaker cells. This might be the result of the slowing of sinuatrial transmission and the resulting prolongation of the refractory state within the junction area. Even in the remaining patients, depressed retrograde conduction of the atrial depolarisations was shown, despite the absence of significant effects on sinuatrial conduction time. The increase in the duration of zone I therefore meant that late atrial reponses reaching the sinus node in the control state might be blocked within the junction after amiodarone. However, these responses were likely to penetrate still deeply into the sinus node area and to die out in the vicinity of the pacemaker cells. According to studies on the rabbit sinus node by Miller and Strauss (1974), electrotonic shortening of the action potential duration of the pacemaker cells might ensue, making the next discharge occur earlier and therefore reducing the A2-A3 interval. This would explain the possible lowering of the terminal part of segment I below the compensatory line, resulting in a smooth transition between both zones.

As for the lengthening of the return cycles observed after amiodarone injection at short coupling intervals, one of two mechanisms may be responsible: either further slowing of the early atrial responses, a result of the prolongation of the relative refractory period within the sinuatrial junction or the atrium itself, or depressed automaticity of the sinuatrial cells after sufficiently premature stimulation (Bonke et al., 1971).

The present data thus support the view that amiodarone impairs sinus node function. The results of premature atrial stimulation suggest that conduction within the sinuatrial junction can be depressed by the drug. Such changes shed light on the possible mechanisms of side-effects in man. In this respect, further studies are required to assess the action of amiodarone in patients with the sick sinus syndrome. A specific factor in the antiarrhythmic activity of amiodarone appears to be its accumulation in the tissues (Rosenbaum et al., 1976); electrophysiological changes are not necessarily the same after prolonged oral treatment as after intravenous injection. These limitations must be kept in mind for proper appraisal of our data.

\section{References}

Barrillon, A., and Himbert, J. (1971). Amiodarone et thyroïde. Presse Médicale, 79, 1498-1498.
Bonke, F. L. M., Bouman, L. N., and Schopman, F. J. G. (1971). Effect of an early premature beat on activity of the sinoatrial node and atrial rhythm in the rabbit. Circulation Research, 29, 704-715.

Cabasson, J., Puech, P., Mellet, J. M., Guimond, C., Bachy, C., and Sassine, A. (1976). Analyse des effets électrophysiologiques de l'amiodarone par l'enregistrement simultané des potentiels d'action monophasiques et du faisceau de His. Archives des Maladies du Coeur et des Vaisseaux, 69, 691-699.

Castillo-Fenoy, A., Valere, P. E., and Tricot, R. (1978). Identification du potentiel sinusal chez le chien par électrocardiographie épicardique. Archives des Maladies du Coeur et des Vaisseaux, 71, 334-339.

Charlier, R. (1970). Cardiac actions in the dog of a new antagonist of adrenergic excitation which does not produce competitive blockade of adrenoreceptors. British fournal of Pharmacology, 39, 668-674.

Coumel, P., and Bouvrain, Y. (1973). Etude clinique des effets pharmacodynamiques et antiarythmiques de l'amiodarone. Fournal des Agrégés, 6, 69-81.

Fauchier, J. P., Brochier, M., and Raynaud, R. (1973). Etude clinique des effets antiarythmiques ventriculaires de l'amiodarone (orale et injectable). Annales de Cardiologie et d'Angéiologie, 22, 427-435.

Francois, J. (1968). Cornea verticillata. Bulletin de la Société Belge d'Ophtalmologie, No. 150, 656-669.

Goupil, L., and Lenfant, J. (1976). The effects of amiodarone on the sinus node activity of the rabbit heart. European fournal of Pharmacology, 39, 23-31.

Grand, A. (1975). Myxoedème à l'amiodarone. Coeur et Médecine Interne, 14, 163-167.

Mandel, W., Hayakawa, H., Danzig, R., and Marcus, H. S. (1971). Evaluation of sino-atrial node function in man by overdrive suppression. Circulation, 44, 59-66.

Miller, H. C., and Strauss, H. C. (1974). Measurement of sinoatrial conduction time by premature atrial stimulation in the rabbit. Circulation Research, 35, 935-947.

Morand, P., Benatre, J., Viau, G., Carli-Basset, C., Laine, J. L., Neel, J. L., Brochier, M., and Raynaud, R. (1972). Etude clinique et histologique (ultrastructure) de la pigmentation par le chlorhydrate d'amiodarone. Semaine des Hôpitaux de Paris, 48, 553-563.

Narula, O. S., Samet, P., and Javier, R. P. (1972). Significance of the sinus node recovery time. Circulation, 45, 140-158.

Pritchard, D. A., Singh, B. N., and Hurley, P. J. (1975). Effects of amiodarone on thyroid function in patients with ischaemic heart disease. British Heart fournal, 37, 856-860.

Rosenbaum, M. B., Chiale, P. A., Halpern, M. S., Nau, G. J., Przybylski, J., Levi, R. J., Lazzari, J. O., and Elizari, M. V. (1976). Clinical efficacy of amiodarone as an antiarrhythmic agent. American fournal of Cardiology, 38, 934-944.

Rosenbaum, M. B., Chiale, P. A., Ryba, D., and Elizari, M. V. (1974). Control of tachyarrhythmias associated with WolffParkinson-White syndrome by amiodarone hydrochloride. American fournal of Cardiology, 34, 215-223.

Scherlag, B. J., Lau, S. H., Helfant, R. H., Berkowitz, W. D., Stein, E., and Damato, A. N. (1969). Catheter technique for recording His bundle activity in man. Circulation, 39, 13-18.

Sicart, M., Besse, P., Choussat, A., and Bricaud, H. (1977). Action hémodynamique de l'amiodarone intra-veineuse chez l'homme. Archives des Maladies du Coeur et des Vaisseaux, 70, 219-227.

Singh, B. N., and Vaughan Williams, E. M. (1970). The effect of amiodarone, a new antianginal drug, on cardiac muscle. British fournal of Pharmacology, 39, 657-667.

Strauss, H. C., Saroff, A. L., Bigger, J. T., jun., and Giardina, E. G. V. (1973). Premature atrial stimulation as a key to the understanding of sino-atrial conduction in man. Circulation, 47, 86-93. 
Touboul, P., Huerta, F., Porte, J., and Delahaye, J. P. (1975). Etude des propriétés électrophysiologiques de l'acébutolol chez l'homme. Thérapie, 30, 417-427.

Touboul, P., Huerta, F., Porte, J., and Delahaye, J. P. (1976a). Bases électrophysiologiques de l'action antiarythmique de l'amiodarone chez l'homme. Archives des Maladies du Coeur et des Vaisseaux, 69, 845-853.

Touboul, P., Porte, J., Huerta, F., and Delahaye, J. P. (1976b). Effets électrophysiologiques de l'amiodarone dans le syndrome de Wolff-Parkinson-White. Archives des Maladies du Coeur et des Vaisseaux, 69, 855-863.

Van Schepdael, J., and Solvay, H. (1970). Etude clinique de l'amiodarone dans les troubles du rythme cardiaque. Presse Médicale, 78, 1849-1850.

Vastesaeger, M., Gillot, P., and Rasson, G. (1967). Etude clinique d'une nouvelle médication anti-angoreuse. Acta Cardiologica, 22, 483-500.
Verin, P., Gendre, P., Barchewitz, G., Laurent-Bronchat, G., Yacoubi, M., and Moran, S. (1971). Thésaurismose cornéenne par amiodarone. Archives d'Ophtalmologie, 31, 581-596.

Wanet, J., Achten, G., Barchewitz, G., Mestdagh, C., and Vastesaeger, M. (1971). Amiodarone et dépôts cutanés. Etude clinique et histologique. Annales de Dermatologie et de Syphiligraphie, 98, 131-140.

Wellens, H. J. J., Lie, K. J., Bär, F. W., Wesdorp, J. C., Dohmen, H. J., Düren, D. R., and Durrer, D. (1976). Effect of amiodarone in the Wolff-Parkinson-White syndrome. American fournal of Cardiology, 38, 189-194.

Requests for reprints to Dr Paul Touboul, Hôpital Cardiovasculaire et Pneumologique, B.P. LyonMontchat, 69394 Lyon Cedex 3, France. 